\title{
THE BRAZILIAN AND PATAGONIAN FISHES OF THE WILKES EXPEDITION
}

$1838-1842$

\author{
By Henry W. Fowler \\ Curator of Fishes, The Academy of Nstural \\ Sciences of Philadelphia U. S. A.
}

Introduction

Rio de Janeiro 1838

Patagonia 1839

Description of Species

\section{INTRODUCTION}

In the voyage around the world the United States Exploring Expedition, often referred to as the Wilkes Expedition, while in the western Atlantic, visited Rio de Janeiro and Patagonia. I listed the fishes of the expedition in a preliminary paper read before the American Philosophical Society in Philadelphia at their anniversary, February 23,1940, or the Centenary celebration (1). Since then I have had acess to the MS. journal by Dr. Charles Pickering, botanist of the expedition. This reveals a lot of valuable items dealing with the natural history in a broad way, details of the localities visited and extensive annotated lists of both animals and plants, besides many other eategories. Historically the comments are often of signal importance. In many instances they form a good basis for comparison in interesting and important faunistic studies.

I have had opportunity to study the entire eollection of the Wilkes Expedition fishes, or such of it as has endured to the present time, ineluding these specimens herein. They are contained in the U. S. National Museum in Washington, D. C., which institution has kindly afforded me every opportunity for their examination and study. I therefore offer the present paper largely for its historical interest, or as an early glimpse of the great marine fauna of Brazil and the upper Argentine.

(1) Proe. Am. Philos. Soc. Philadelphia, vol. 82. n. ${ }^{\circ}$ 5, 1940, pp. 733-800, figs, 1.76 (outlines). 


\section{RIO DE JANEIRO 1838}

November 23. The Bay of Rio de Janeiro at its entrance, the most contracted part (between the forts), is about one geographic mile in breadth. it enlarges almost immediately and continues of the average width of nearly 3 geographic miles, to the upper part of the city, a distance of about 5 geographic miles. Beyond the eity the bay expands into an oval form, trending a little eastwardly, $16^{\prime}$ in extreme length with a mean breadth of about $9^{\prime}$. It receives the waters of a number of small streams, the most considerable of which is the Macaeie, having a direct course of about $34^{\prime}$ and draining an extent of surface of equal width. Eight other streams, having an average course of $15^{\prime}$ enter the upper part of the bay, principally around its northwestern border; the remainder are unimportant. On the whole, the little isolated basin containing the Bay of Rio, may be at $60^{\prime}$ in length, from east to west, by $30^{\prime}$ in breadth.

Besides the "Ilha do Governador" which is of considerable size, the bay contains a great number of rocky islets, and in various places, rocks projecting above the surface. Its shores are very much indented and a map of large seale would be required to represent their actual configuration; rocky promontories jut out in every direction, between which are sandy beaches or the marshy outlets of the streams. Towards the upper part of the bay, where the streams are more considerable, the marsh predominates and the promontories are now distant and less elevated. The sea coast again presents the same general features - lofty promontaries project at intervals, round the base of which it is most usually impossible to pass. To the eastward of the bay and behind a considerable reach of sea beach, lies a shallow lagoon of brackish water, called the "Laguna de Peteningu"; and to the westward in a similar situation, the "Lagoa de Freitas". At the time of our visit these did not communicate with the ocean, but we were told the surf sometimes breaks over into them. Further to the westward lies the still more extensive lagoon, commonly called the lake of Tijuca, but no real fresh-water lake is anywhere to be found. The islands outside of the bay, as may be anticipated, are rounded lumps of granite.

December 9. From the summit of the Estrella pass the descent had been very gradual and we were yet apparently at a very considerable elevation. Our stopping place was at a cluster of small houses, on the bank of the river, near the bridge on the road leading to Mr. March's residence. We were surprised at the volume of water and searched its rocky bed for fresh-water shells, but neither here nor in all this journey could we find the least trace, or a fresh-water fish, although we looked at every favorable opportunity. It may be that the streams were too much swelled by the rains. (2)

(2) I use this letter to indicate the excerpts from the Pickering journal. 
Clupeidae

Clupea arcuata Jenyns

Depth $37 / 8$; head $37 / 8$. Snout $31 / 5$ in head from tip of upper jaw; eye $31 / 3$; maxillary 2 , not quite reaching opposite front of pupil; mandible protrudes; interorbital 5 in head from tip of upper jaw; opercle and cheek smooth. Gill rakers $13+32$, fine, slender, 2/5 longer than gill filaments, or equal eye. Inside gill opening entire. Scales 37 ? in axial lateral series to caudal base. Scales thin, very caducous; circuli very fine, in parallel convex courses, though many irregular over greater basal portion, none apical. Serrae $18+13$. D. $I I I, 14$ ?, origin midway between hind pupil edge and caudal base; A. III, 16? Ventral origin slightly before dorsal origin. Length $87 \mathrm{~mm}$. to end of damaged caudal.

Agrees with Jenyn's imperfect account, except he compares it with Clupea harengus Linnaeus and says "teeth the same, and very minute" which would infer the presence of vomerine teeth, thongh such are not present in the above specimen.

\section{Sardinella allecia (Rafinesque)}

Depth $41 / 5$; head $33 / 5$, width $21 / 5$ in its length. Snout $31 / 2$ in head from tip of upper jaw; eye $41 / 6$, adipose lids broad; maxillary $21 / 2$, reaches opposite front of pupil; scarcely any teeth in jaws; each palatine and upper surface of tongue with bands of fine simples teeth; interorbital 5, level; cheek and preopercle with wide set radiating lines, opercles smooth. Gill rakers $70+130$, very slender, fine, little longer than gill filaments. Scales $47+5$ in lateral series, 14 ? transversely from dorsal origin; 23 predorsal; vertical striae 4 or 5 , usually divided medianly, or at least most all except outermost. Serrae $19+14$. D. $I I I$, 15 ; A. III, 13 ?; pectoral $I, 15$; ventral $I$, 8 . In alcohol brown on back, sides and below pale brassy brown. Fins dull. One, $135 \mathrm{~mm}$. "Callao", likely from Rio de Janeiro, and like one but $67 \mathrm{~mm}$. long. Drawing from specimen $150 \mathrm{~mm}$. by Richard, from Rio de Janeiro.

\section{Harengula majorina Storey}

Drawing of a specimen $124 \mathrm{~mm}$. long from Rio de Janeiro.

\section{Brevoortia pectinata Jenyns}

Depth $25 / 6$; head $31 / 4$. Snout $33 / 4$ in head from upper jaw tip ; eye 6 ; maxillary $21 / 6$; interorbital $23 / 4$. Gill rakers 85 to 90 on ceratobranchial of first arch. Scales $55+5$ in axial lateral series; 25 transversely from dorsal origin; 46 predorsal; scales with 15 to 24 apical serrae. Three specimens, largest noted above $200 \mathrm{~mm}$. long to end of broken caudal, all from Rio de Janeiro. Drayton's painting of a specimen 
$160 \mathrm{~mm}$. long, dated December 1839 and Richard's drawing is from a specimen $230 \mathrm{~mm}$. long.

I compared a series of the elosely related $B$. tyrannus (Latrobe) in the Academy, from Massachusetts, New Jersey, Delaware, Maryland, and the Carolinas. These show: Depth $22 / 5$ to $31 / 5$; head $23 / 4$ to $31 / 5$. Snout $32 / 5$ to $41 / 4$ in head from upper jaw tip; eye $31 / 2$ to to $61 / 2$; maxillary 2 to $21 / 4$; interorbital $34 / 5$ to $41 / 2$. Scales 45 to 77 , usually 50, fewer in young and more in adult; 5 to 8 scales on caudal basally; 21 to 28 transversely from dorsal origin, usually $23 ; 26$ to 45 predorsal, usually 30 . Serrae 17 to $22+11$ to 14 . A New Jersey specimen $250 \mathrm{~mm}$. long has 70 lower gill rakers, compared with $80+140$ usually counted. Seales with 30 to 40 apical serrae.

\section{Engraulidae}

\section{Anchoa tricolor (Agassiz)}

Anchoviella salvatoris Fowler and Bean, Proc. U. S. Nat. Mus., vol. 63, 1923, p. 6. Rio de Janeiro, Brazil. - Fowler, Proc. Am. Philos. Soc., vol. 82, n. $^{\circ} 5,1940$, p. 747 , fig. 12 (type).

Hildebrand says the type is in bad condition, but apparently may be identified with Anchoa tricolor (Bull. Bingham Ocean. Coll., vol. 8, art. 2,1943 , p. 74$)$.

\section{Tetragonopteridae}

Astyanax fasciatus (Cuvier)

Depth $22 / 5$; head 4 . Snout $33 / 4$ in head; eye $24 / 5$; maxillary $22 / 5$, apparently toothless; interorbital $23 / 4$, separated from preopercle ridge. Gill rakers $7+11$, lanceolate. Seales $33+2$ ? in lateral line, 7 above, 6 below, 15 predorsal. Seales with 8 to 11 apical marginal striae; basal circuli moderately fine. D. $I I, 8 ; \mathrm{A} . I I, 24$ ?. In alcohol dull brown, with obscure brassy band along middle of side, wide as eye. Dull dusky humeral blotch, little smaller than eye, just above origin of lateral line. Length (without caudal) $60 \mathrm{~mm}$. Without locality, likely from Rio de Janeiro?

\section{Ophichthidae}

\section{Oplichthus gomesii (Castelnau)}

Depth $261 / 3$; head $93 / 4,32 / 5$ to vent, width $32 / 3$ its own length. Snout $53 / 4$ in head, conic, width $11 / 5$ in its length; eye $12 / 3$ in snout, without eyelids; gape of mouth $27 / 8$ in head, extends half an eye diameter beyond mandible; teeth conic, biserial in jaws and on vomer; front of upper jaw with double row of 6 slightly larger teeth before 
mandible tip ; front nostril in short, broad, simples tube in upper lip, opposite closed mandible tip; hind nostril slit in upper lip below front eye edge; interorbital width 7 in head, level. Gill opening $11 / 8$ in snout. Dorsal origin over last fifth in depressed pectoral. Anal little lower than dorsal. End of tail moderately compressed, slender, and last dorsal and anal rays slightly elongate. In alcohol uniform dull brown. Vertical fins slightly darker or deeper brown marginally. Pectoral $21 / 2$ in head. Length $413 \mathrm{~mm}$. Specimen without locality, but according to Richard's drawing in 1858, Rio de Janeiro given as locality.

Comparison with an example in the Academy $635 \mathrm{~mm}$. long (not $400 \mathrm{~mm}$. as stated by Fowler, Proc. Acad. Nat. Sci. Phila., 1917, p. 131). It has the nasal tube with a distinct pointed barbel.

Ophisurus gomesii Castelnau (An. Am. Sud. Poiss., 1855, p. 84, pl. 44, fig. 2. Rio de Janeiro) is described with 3 rows of teeth on the palate. The figure shows the dorsal beginning directly behind the tip of the pectoral fin, eye large and the nasal tube simple or without indication of a barbel.

\section{Echidnidae}

\section{Lycodontis occelatus (Agassiz)}

Depth at vent $154 / 5$ to $221 / 3$; head $71 / 4$ to $81 / 2$, width $31 / 3$ to $31 / 2$ in its length and pharynx swollen. Snout 5 in head, width 1 to $11 / 8$ in its length; eye 8 to $91 / 2$, with front edge or front pupil edge midway in gape, diameter $12 / 5$ to $12 / 3$ in snout; gape $21 / 2$ to $24 / 5$ in head, mouth completely closing; jaws nearly even, or lower slightly shorter; lips rather thin, minutely papillete; teeth minutely serrated, compressed, uniserial, inclined back, front ones canine like; median front canines and 2 pairs at front depressible inwards above, all erect below; vomer with median row of small conic teeth beginning below front eye edge; front nostril simple pore near snout tip; hind nostril simple pore well elevated in interorbital above front pupil edge; interorbital $61 / 2$ to 8 in head, convex; mandible $15 / 6$ to $21 / 5$. Gill opening $11 / 3$ to 2 in eye. Dorsal inserted at last $2 / 5$ in space between hind eye edge and gill opening.

Color in alcohol largely rich brown, marked very obscurely with dusky. Many small buff or creamy spots on trunk, in 6 or 7 lengthwise series and on tail gradually decreasing until terminally only 2 or 3 alternate dark and pale large blotches. Body spots, except on tail end, smaller than interspaces and none much larger than pupil. On head spots not much more erowded than on pharynx, though equally small. Eye rim dark brown, also gill opening. Dorsal with a number of rather large blackish marginal blotehes, this more or less alternated on lower part of fin with larger or paler blotches. Anal broadly and entirely edged blackish. Iris grayish. Mouth pale inside. Length $453 \mathrm{~mm}$. Besides the 
Wilkes specimen, without locality though doubtless from Rio de Janeiro, I also include a specimen from Santo Domingo, W. I., $420 \mathrm{~mm}$. lọg, in the Academy. It agrees largely with the original figure by Agassiz (Pisc. Brasil. Spix, 1828, p. 91, pl. 50 b). That shows the white spots of uneven size, some large as the pupil and others smaller, dorsal and anal edges with many various white spots, of which some small and others much larger than the eye, the black interspaces often equally large.

\section{Cyprinodontidae}

\section{Fitzroyia lineata (Jenyns)}

Depth $31 / 8$; head 3 , width $12 / 3$ in its length. Snout 3 in head from tip of upper jaw, depressed, half long as wide; eye 3 , high, next to upper profile; maxillary 3 ; jaws greatly protractile, with lower protruding; teeth in jaws tricuspid, outer series enlarged and form close set row all around, behind which 7 irregular rows form broad band; maxillary vertical, hind edge $3 / 4$ in snout; interorbital $21 / 8$ in head from snout tip, flat. Gill rakers $1+8$ short robust points. Seales $26+4$ in axial lateral row, 9 transversely between dorsal and ventral origins, 14 predorsal forward to head. Seales adherent; basal horizontal parallel marginal striae 10 to 20 ; circuli rather fine, apically coarse. D. $I I, 6$, inserted little nearer gill opening than caudal base, depressed fin reaching half way to latter; A. $I I, 7$, origin opposite first third of dorsal base, fin extending back further; rounded caudal $11 / 3$ ? in head; pectoral $14 / 5$; ventral $23 / 4$. Anal opening fleshy and genital pore with slight or low sheath, entirely before anal fin. Color in alcohol dull brownish, little paler below. Each row of scales on sides with median dark brown narrow line, sometimes broken or with spotted appearance and lower lines paler. Fins brownish, ventral and anal quite pale. Iris brown. Length $57 \mathrm{~mm}$.

Jenyns originally described this species (Voy. Beagle, Fish. vol. 4, 1842 , p. 116 , pl. 22 , fig. 2) from a slightly smaller example obtained at Maldonado, Uruguay. He gives the teeth as "a single closely-set series".

\section{Poeciliidae}

\section{Phalloptychus januarius (Hensel)}

Depth $31 / 4$ to $31 / 3$; head 3 to $33 / 4$, width $11 / 2$ to 2 in its length. Snout 4 to $41 / 2$ in head from tip of upper jaw, depressed, length $1 / 2$ to $2 / 3$ its width; eye $21 / 2$ to 3 in head from snout tip; maxillary $31 / 8$ to 4 ; mouth small, jaws greatly protractile and lower well protruding; teeth uniserial, small, simple, close set; interorbital $14 / 5$ to $21 / 6$, level. Seales 30 or $31+3$ or 4 in axial lateral series, 9 transversely between 
dorsal and ventral origins, 17 predorsal forward to head; scales with basal parallel marginal striae 11 or 12 in male, 17 in female; circuli coarse. D. $I I, 5$ or 6 , origin midway between hind preopercle edge and caudal base in male, midway between pectoral origin and caudal base in female; A. 5, origin in male nearer snout tip than caudal base, in female midway between hind preopercle edge and caudal base; gonopodium nearly half body length, reaches caudal base. Brownish in alcohol. Male $18 \mathrm{~mm}$., 2 females $28 \mathrm{~mm}$. Rio de Janeiro.

The gonopodium agrees with Regan's figure (Proc. Zool. Soc. London 1913 , p. 999, fig. $171 \mathrm{~A}$ ) except that the terminal serrae of the second ray are not twisted forward.

\section{Phalloceros caudimaculatus (Hensel)}

Depth 3 to $33 / 4$; head $31 / 6$ to 4 , width $12 / 5$ to $13 / 4$ in its total length. Snout $31 / 3$ to 4 in head from tip of upper jaw; eye $21 / 3$ to 3 ; mouth small, jaws greatly protractile and lower well protruded; teeth uniserial, small, simple, close set, rather blunt; interorbital 2 to $21 / 2$ in head from snout tip, level. Seales 28 to $30+3$ or 4 in axial lateral series, 8 to 10 transversely between dorsal and ventral origins, 16 or 17 predorsal; scales of male with 12 or 13 basal parallel marginal striae, 13 to 16 in female, and eirculi of both rather coarse. D. $I$ to $I I I, 6$ or 7 , in male inserted midway between hind edge of eye or gill opening and caudal base, in female midway between gill opening and candal base; A. $I$ to $I I I, 6$ or 7 ; young male with anal origin nearer snout tip than end of depressed gonopodium, midway in large specimens; gonopodium 2 to $21 / 4$ in body to eaudal base. Color in alcohol brownish, lower surface uniformly pale. Edges of each scale dark, forming a reticulating pattern. Vertical dusky bloteh below last dorsal rays. Twelve narrow dark brown verticaI streaks in male, more wide spread on caudal peduncle and a dark spot at caudal base. Length 20 to $38 \mathrm{~mm}$.

Besides the single specimen in the Wilkes collection, the 'smallest, I include 2 females in the Academy from Rio Grande do Sul, and a male and female from Puerto Bertoni, Paraguay.

Poecilia vivipara Schneider

Depth 3 ; head 3 to $32 / 3$, width $11 / 4$ to $12 / 5$ in its length. Snout $31 / 4$ to $32 / 5$ in head broad, depressed, length half its width; eye $31 / 5$ to $31 / 4$; mouth width $22 / 5$ to $22 / 3$; teeth fine, slender, ends spatulate in those of outer row and finer minute parallel teeth in inner row interorbital width $17 / 8$ to 2 in head, flat. Gill rakers 22 short flexible points on ceratobranchial. Seales 24 to $27+5$ to 7 in axial lateral series, 9 transverseley between dorsal and ventral origins, 13 predorsal forward to head; seales with 13 to 16 short basal parallel marginal striae in male, to 19 in female. D. I, 6, origin midway between hind eye edge and caudal base in male, midway between pectoral origin and 
caudal base in female; A. I, 6 , in male first and second rays prolonged, without appendages, ends with cutaneous hood, spineless and first ray with several segments terminally forming acute serrations; pectoral $11 / 8$ to $11 / 4$ in head; ventral with second ray eloganted.

Color in alcohol dull brownish, paler below. Scale edges on back mostly darker than ground color. Male with at least 7 narrow dark vertical cross bars or lines, and above black blotch little smaller than eye near pectoral end, sometimes ocellate or with pale edge. Transverse blackish bar on dorsal subbasally and sometimes several darker blotehes above. Adult male with caudal edges above and below narrowly blackish, especially about rudimentary rays. Female also shows blackish blotch on back behind pectoral end, or close before dorsal, and another from ventral axil toward anal origin, but latter not seen in male. Both sexes usually show 2 or 3 cross bars on caudal. Female with less conspicuous markings or only faint cross bars on dorsal and eaudal. Males 33 to $48 \mathrm{~mm}$. in total length, females 47 to $60 \mathrm{~mm}$. Six from Rio de Janeiro. I have also compared specimens in the Academy from Surinam.

\section{Belonidae}

\section{Strongylura timucu (Walbaum)}

Depth $11 / 4$ to $11 / 2$ in postocular length; head measured from upper jaw tip $24 / 5$ to 3 , its width $12 / 3$ to $14 / 5$ in postocular. Front end of frontal extension to eye 4 in rest of upper jaw length, equals width at eye; eye $23 / 4$ to $33 / 5$ in postocular, elose to upper profile, but not impinging; jaws not completely closing basally and lower with fleshy tip longer than upper by nearly pupil length; maxillary well exposed below, extends slightly beyond front of eye, though not to pupil; either band of teeth narrow, very fine, inner well spaced; triangular nasal eavity long as pupil; interorbital $21 / 5$ to $21 / 3$ in postocular, level, with broad even shallow depression medially, only about half way to occiput. Bones of head above with rather obsolete coarse striae. Gill opening extends forward $2 / 5$ or little less than half of eye. Scales 218 to 260 in axial lateral series to caudal base, 150 to 200 predorsal; scales with 33 to 45 cireuli, incomplete down median axis with age; middle of back with 3 rows of enlarged seales; 16 or 17 rows of scales on cheek to preopercle. Lateral line with short branch to pectoral base, ascends after dorsal midway along side of caudal peduncle. D. II, 13 or 14, origin slightly behind anal origin or at last fourth between eye and caudal base, with lobe in front and anal similar, only little larger; A. II, 14 to 16 ; caudal little emarginate behind, lower lobe little longer, equals postorbital and half of eye; pectoral elevated, $1 / 4$ to $1 / 3$ of eye longer than postocular; ventral inserted midway between ridge and caudal base, slightly advanced with age, length $12 / 3$ to $13 / 4$ in postocular. 
Color in alcohol dull brownish, paler to silvery white below. Narrow whitish streak along side, begins well behind pectoral and widest equals pupil diameter, opposite front of dorsal and anal and continued to caudal. Fins brownish, ventral, anal and pectoral little paler. Dorsal and anal lobes, eaudal and pectoral, with some dusky terminally. Length 380 to $490 \mathrm{~mm}$. One from Rio de Janeiro, and other specimens examined in the Academy from Santo Domingo, W. I., and Colon, Panama.

\section{Hemiramphidae}

Hyporhamphus salvatoris Fowler and Bean

Hyporhamphus salvatoris Fowler and Bean, Proc. U. S. Nat. Mus., vol. 63, art. 19, 1923, p. 9. Rio de Janeiro.

Type n. ${ }^{\circ}$ 83.286. U. S. N. M. Rio de Janeiro.

\section{Exocoetidae}

\section{Cypsilurus furcatus (Mitehill)}

Two colored figures, labeled from off Cape Frio, near Rio de Janeiro.

\section{Gadidae}

Urophycis latus . Ribeiro

Depth $53 / 5$; head $41 / 6$, width 2 in its length. Snout $31 / 2$ in head, conic, length $2 / 3$ its width; eye $51 / 8$ in head; mouth large, lower jaw shorter; maxillary 2 , reaches slightly beyond eye, expansion $11 / 4$ in eye; teeth simple, conie, in bands in jaws and on vomer; interorbital $41 / 2$ in head, broadly convex. Gill rakers $3+11$, lanceolate. Seales 123 along lateral line to eaudal base, 12 above to soft dorsal origin, 38 below to anal origin, 62 forward until opposite nostrils; seales cycloid, circuli 20 to 28 , not joined medially or basally. D. VIII -57 , filamentous first ray $31 / 8$ in total length of fish; A. 47; pectoral 18; ventral 3, length 2 in combined head and trunk. Color in alcohol uniform pale brown. Length $220 \mathrm{~mm}$. Rio de Janeiro.

\section{Bothidae}

\section{Paralichthys orbignyana (Valenciennes)}

Xystreurys ribeiroi Fowler and Bean, Proc. U. S. Nat. Mus., vol. 63, art. 19, 1923, p. 26. Rio de Janeiro.

Type of $X$. ribeiroi Fowler and Bean, n. ${ }^{\circ} 83.404$ U. S. N. M. This is given as an outline figure by Norman (Syst. Monogr. Flatfishes, vol. 1, 1934, p. 72, fig. 38 a). 


\section{Soleidae}

\section{Achirus achirus (Linnaeus)}

Depth $13 / 5$; head $31 / 3$. Snout to upper eye, 4 in head; upper eye $41 / 4$; maxillary $27 / 8$; pectoral $11 / 3$. D. 50 ; A. 44 . In alcohol uniform brownish on right side, paler on left side. Length $35 \mathrm{~mm}$. Rio de Janeiro.

In my list of coastal Brazilian fishes (Arq. Zool. Estado São Paulo vol. 3, art. 6,1941 , p. 145) I overlooked the following:

\section{Achirus mentalis (Guenther)}

Solea mentalis Guenther, Cat. Fishes Brit. Mus., vol. 4, 1862, p. 475. Pará. Achirus mentalis Jordan and Goss, Rep. U. S. Fish. Comm., pt. 14, 1886 (1889), p. 313 (reference).

\section{Cynoglossidae}

\section{Symphurus plagusia. (Schneider)}

Depth $31 / 3$; head $43 / 4$, width 4 in its length. Snout to upper eye 5 in head; upper eye $73 / 4$; maxillary extends beyond hind pupil edge of lower eye, though not quite to hind eye edge; mandible from tip to rictus $42 / 5$ in head; band of fine teeth in each jaw on blind'side; interorbital less in width than pupil and front nostril in its front part. Seales 90 from above gill opening to caudal base, 40 transversely at widest point of body; scales with 21 to 23 radiating basal striae, edges finely scalloped; apical denticles 21 to 23 , slender; circuli fine; seales alike on both sides of body. D. 96 ; A. 80 . Color in alcohol uniform dull brown on left side, pale or whitish on right side. Length $105 \mathrm{~mm}$. Rio de Janeiro.

\section{Holocentridae}

Corniger spinosus Agassiz

Depth $21 / 4$; head $22 / 3$, width $14 / 5$ in its length. Snout 4 in head; eye $32 / 5$, high; maxillary 2 , extends little beyond hind pupil edge, expansion $11 / 3$ in eye; mouth oblique, jaws even; teeth minute, in bands in jaws, bands much narrower on palatines and small patch on vomer; interorbital 6 in head, narrow and slightly convex; each prenasal with 4 small spines directed forward; lower edge of suborbitals with 4 large spines though first much smaller than others and all directed backward; preopercle angle with large spine and 1 close above and another close below, all directed back; opereular spine large; all bones on head quite spinescent. Gill rakers $I I I, 3+10, I I I$, lanceolate. Seales $30+5$ in 
lateral line, 4 above to spinous dorsal, 7 below to spinous anal, 6 predorsal. Scales coarsely ctenoid; long apical denticles 14 to 16 ; basal circuli extremely fine; cheek with 4 rows of seales. D. XII, 14, I, origin oposite pectoral origin, third spine $21 / 6$ in head; A. IV, 10, I, third spine $22 / 3$ in head; pectoral $12 / 5$; ventral $12 / 3$. Color in alcohol pale uniform brownish. Length $168 \mathrm{~mm}$ ? Rio de Janeiro.

\section{Syngnathidae}

Syngnathus rosseau Kaup

Depth 3 to 4 in head, body well compressed; head $21 / 3$ to $31 / 8$ to vent, width $31 / 4$ to 5 in its length. Snout $17 / 8$ to $21 / 3$ in head as measured from tip of upper jaw, shorter in young; eye $21 / 4$ to 3 in snout, larger in young, also supraorbital keel; mouth terminally superior; maxillary half length of eye; interorbital 1 to $13 / 4$ in eye, concave, rostral keel extending within though much less developed than on snout; opercle without keel, with many fine striae radiating above and below; slight occipital keel medianly, notehed at each segment juncture. Gill opening small slit nearly or quite horizontal, 2 to 4 times its own length from pectoral origin. Rings firm and without spines on keels, though ring with many fine transverse striae; upper keel each side of back to last fourth to sixth in dorsal fin length; this replaced below by similar parallel or upper eaudal keel, beginning at first fifth to fourth in dorsal fin length; median lateral keel from pectoral axil midway along side, ends opposite where caudal keel begins; median ventral keel complete from breast to vent; lower lateral keel on each side from head to caudal fin uninterrupted. Male with brood pouch extending over 12 to 15 rings. Rings 17 (once 18) +32 or 33 (once 27 ). D. 25 to 31 , inserted usually well forward in second ring before vent and extends on 5 body rings; A. 3, nearly long as eye, inserted on ring just behind vent; caudal $11 / 4$ to $21 / 2$ in snout; pectoral $21 / 5$ to 3 . In alcohol faded dull brown, some dark specks and streaks on sides and above. Four from Rio de Janeiro. Length 79 to $115 \mathrm{~mm}$.

Hippocampus villosus Guenther

Drawings of 3 specimens from Rio de Janeiro.

\section{Atherinidae}

Xenomelaniris brasiliensis (Quoy and Gaimard)

Depth $42 / 3$, well compressed body with flattened sides constricted below; head $41 / 8$, width $14 / 5$ in its length. Snout 3 in head, broadly depressed, length $4 / 5$ its width; eye $31 / 2$ in head; mouth with short 
curved gape, upper jaw slightly longer; maxillary 3 , largely eoncealed above, reaches beyond front of eye though not quite to pupil; narrow of small curved conic teeth in jaws and each with outer row of few irregular larger similar ones, best developed near front above and on sides below; palate toothless; interorbital width 3 , wide, very slightly convex. Gill rakers $5+13$, lanceolate. Scales $39+5$ in axial lateral series, 9 transversly from soft dorsal origin, 20 predorsal forward to head; seales firmly adherent, narrowly exposed, each with 1 or 2 basal points; 50 basal circuli parallel with edge, and apical portions and edges entire. Lateral line as 7 tubular seales close above depressed pectoral, then drops 1 scale and continues midway along side to caudal base medially. D. III - II, 7, spinous fin inserted midway between pectoral origin and caudal base; A. II, 19, inserted before spinous dorsal origin; fin base extends back slightly beyond second dorsal base; pectoral rays $I$, 13 , fin $11 / 8$ in head; ventral $I$, 5 , fin $21 / 6$ in head.

Color in alcohol olive brown, little paler below. Fins all brown. Iris silvery. Narrow brassy lateral band, less than eye in greatest width above anal, contains first part of lateral line and then continues throughout same row of seales above rest of lateral line to caudal base medially. Length $103 \mathrm{~mm}$. to end of broken caudal. Rio de Janeiro.

As Thyrina brasiliensis I have given an outline figure of the above (Proc. Am. Philos. Soc., vol. 82, n. ${ }^{\circ}$ 5, 1940, p. 763, fig. 39).

\section{Mugilidae}

\section{Mugil curema Valenciennes}

Depth $35 / 6$; head $35 / 6$. Snout $32 / 5$ in head; eye $32 / 5$; mouth width $32 / 3$; interorbital $21 / 4$. Scales 40 in axial lateral series to caudal base, 13 transversely from soft dorsal origin, 14 predorsal forward to head; seales with 10 to 12 basal striae. D. IV - I, 8; A. III, 9. Length $170 \mathrm{~mm}$. Rio de Janeiro.

\section{Sphyraenidae}

\section{Sphyraena tome Fowler}

Depth $73 / 4$; head $29 / 10$, width $35 / 6$ in its total length. Snout $21 / 4$ in head from tip of upper jaw; eye $51 / 8,23 / 5$ in snout; maxillar reaches $5 / 6$ to eye, expansion 2 in eye, length $23 / 5$ in head from snout tip; dentition as in type specimen; interorbital $54 / 5$, slightly elevated. largely depressed medianly. Scales $130+7$ in lateral line, 16 above lateral line to spinous dorsal origin, 12 above to soft dorsal origin, 12 below to spinous anal origin, 50 predorsal forward to occiput; scales with 45 to 55 basal radiating striae, many incomplete and variable ( 35 in type). D. V-II, 8 ; A. II, 8; although pectoral damaged apparently would reach 
over $3 / 4$ to spinous dorsal. Color in alcohol uniform dull brown, but little paler below. Length $245 \mathrm{~mm}$. Rio de Janeiro.

Compared with the type of S. tome, now in the Academy. S. branneri Ribeiro appears to differ from this species chiefly in the presence of 2 more spines in the first dorsal and its seales are given as 114 in the lateral line.

\section{Polynemidae}

Polydactylus virginicus (Linnaeus)

Depth 3 to $31 / 2$; head $31 / 4$ to $32 / 3$, width $21 / 10$ to $21 / 5$ in its length ( $23 / 4$ in young). Snout 5 to $61 / 6$ in head (6 in young), obtuse, convex, length in profile $3 / 4$ its width ( $3 / 5$ in young); eye $41 / 3$ to $43 / 4$ ( $21 / 10$ in young), covered by broad adipose eyelid extending back little more than middle in head length; mouth moderate, tip of upper jaw opposite hind nostril, lower jaw included; maxillary reaches beyond eye for space $3 / 5$ of eye diameter, length $21 / 5$ to $21 / 4$ in head (2 1/10 in young), expansion $13 / 4$ to $17 / 8$ in eye; bands of minute villiform teeth in jaws, on vomer and palatines; interorbital $32 / 3$ to $42 / 5$ in head (3 1/2 in young), convex; hind preopercle edge denticulate, denticles largest below. Membranous supraseapula with short strong spine. Gill rakers $I I, 12+17, I I$, lanceolate. Seales 59 to 68 in lateral line to caudal base; 6 to 8 above to spinous dorsal origin; 7 to 9 above to soft dorsal origin; 10 to 13 below to spinous anal origin; 31 to 38 predorsal scales; head sealy; all fins more or less covered with small scales; scales with basal radiating striae 5 to 7 , apical denticles 80 to 110 and eirculi moderate. D. VIII - I, $12, I$, third spine $11 / 4$ to $11 / 2$ in head, first ray $11 / 3$ to $11 / 2$; A. III, $13, I$, third spine $31 / 10$ to $41 / 4$ in head, first ray $11 / 2$ to $14 / 5$; caudal deeply forked, long slender pointed lobes with upper $1+1 / 5$ to $1+1 / 3$ times head; pectoral $11 / 5$ to $11 / 4$, filaments 7 , extend beyond depressed pectoral and ventral, but not quite to anal origin; ventral 2 in head.

Color in alcohol dull brown, apparently stained. Lower surfaces paler. Fins brown. Dorsals with minute dusky brown dots on outer surfaces, spinous fin slightly darker. Ventral, anal and eaudal brownish, first with smutty appearance. Pectoral largely with dusky lavender tinge, filaments whitish. Length 145 to $285 \mathrm{~mm}$. Two from Rio de Janeiro.

Also 3 in the Academy from Santo Domingo, W. I., included above.

\section{Thunnidae}

\section{Neothunnus albacora (Lowe)}

Painting by Drayton of an example 2 feet 10 inches long from S. lat. $0^{\circ} 20^{\prime} \mathrm{W}$. long. $30^{\circ} 30^{\prime \prime}$ (east of Cape St. Roque). 


\section{Trichiuridae}

Trichiurus lepturus Linnaeus

Outline drawing of a specimen $482 \mathrm{~mm}$. long from Rio de Janeiro.

\section{Carangidae}

\section{Oligoplites saurus (Schneider)}

Depth $31 / 2$ to $35 / 6$, body elongately oroid; head 4 to $42 \% 3$, width $21 / 4$ to $22 / 5$ in total head length. Snout $31 / 8$ to $37 / 8$ in head, long as wide; eye $31 / 2$ to $41 / 2$ ?; mouth large, well inclined, jaws nearly even; maxillary $12 / 3$ to $17 / 8$, reaches opposite hind eye edge, little shorter or to hind pupil edge in young; teeth biserial in jaws, lower outer slightly longer and villiform teeth on palatines, vomer and tongue; infraorbitals and suborbitals broad, lower wider, though little less than eye or $1 / 3$ in young; interorbital $32 / 5$ to $33 / 4$ in head. Gill rakers 5 to $7+12$ to 15 , lanceolate. Scales elongate, slender, very compact. Lateral line with slight arch over pectoral. D. I, V - I, 19 or 20, fourth erect spine 3 to $37 / 8$ in head, first branched ray $13 / 4$ to 2 ; A. II, $I, 19$ to 21 first branched anal ray $13 / 4$ to 2 in head; pectoral $13 / 5$ to $14 / 5$; ventral $12 / 3$ to $17 / 8$. In alcohol leaden brown above, sides from level with eye and below bright silvery white. Fins pale brown, ventrals burnished with silvery white. Length 115 to $175 \mathrm{~mm}$. One without locality, likely from Rio de Janeiro, I have also included specimens in the Academy from North Carolina, Florida, Porto Rico and Trinidad, in the above account.

O. rathbuni Ribeiro (Arch. Mus. Nac. Rio de Janeiro, vol. 17, 1915, p. 8 ) is said to differ in its gill rakers $3+13$ and eye $31 / 6$ in head.

\section{Oligoplites saliens (Bloch)}

Depth $31 / 4$; head $41 / 6$. Snout 4 in head from upper jaw tip; eye 4 ; maxillary $11 / 2$; interorbital 3 . D. I, IV - I, 20; A. II - I, 19 . Gill rakers $I I, 4+9, I I I$. Length $215 \mathrm{~mm}$. One without locality, likely from Rio de Janeiro? Compared with specimens in the Academy from the same locality and Trinidad I., W. I.

Drawing in the Wilkes Collection of a specimen from Rio de Janeiro. Selar crumenophthalmus (Bloch)

Two without locality, possibly from Rio de Janeiro?

Caranx latus Agassiz

Depth $22 / 3$; head $32 / 5$, width $21 / 5$ in its total length. Snout $27 / 8$ in head from upper jaw tip, width $11 / 5$ in its length; eye $44 / 5$, 
broad adipose lid covers its last third; mouth little inclined from horizontal, lower jaw slightly protruding; maxillary $22 / 5$, reaches opposite pupil, expansion $12 / 5$ in eye; row of conic teeth in each jaw little larger in front and above followed by narrow band of villiform ones close behind; lower teeth more closely set and little smaller than upper outer ones; villiform teeth on vomer, palatines and tongue; interorbital $33 / 4$ in head from snout tip, convexly elevated. Gill rakers $5+21$, lanceolate. scales $75+30$ in lateral line; scales adherent, simple, cycloid, with eirculi 50 to $55 ; 22$ rows on cheek; breast entirely covered with close set seales. D. I, VIII - I, 22, front lobe $11 / 3$ in fin base; A. II - I, 19, front lobe $1.1 / 8$ in total head length; ventral $21 / 6$; pectoral reaches 14th scute of lateral line. In alcohol dark brown, nearly uniform. No trace of dark spot on operele. Length $285 \mathrm{~mm}$. to end of damaged caudal. No locality, likely the tropical Atlantic at Rio de Janeiro?

Two very young specimens of the present genus, from Rio de Janeiro, are indeterminable specifically.

\section{Caranx ruber (Bloch)}

Depth $22 / 3$; head $31 / 3$, width 2 in its length. Snout $31 / 4$ in head from upper jaw tip, long as wide; eye $32 / 3$; mouth oblique, lower jaw slightly protruded; maxillary $22 / 3$ in head from snout tip, reaches beyond front eye edge, but not quite to pupil, expansion $12 / 3$ in eye; teeth minute, little developed, few as single row in each jaw; minute teeth on vomer, palatines and tongue; interorbital $31 / 8$ in head from snout tip, convexly elevated. Gill rakers $15+32$, lanceolate. Scales $55+45$ in lateral line; scales adherent, nonstriate, with circuli 17 to 28 ;

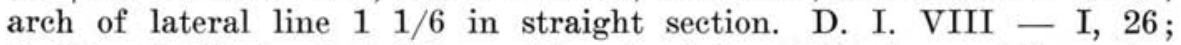
A. II - I, 24. In alcohol brownish, paler below. Fins brown. Opereular spot small, faded. Length $77 \mathrm{~mm}$. to ends of damaged caudal. Without locality, may have been Rio de Janeiro?

The above is wrongly reported by me as Caranx crysos (Proc. Am. Philos. Soc., vol. 82, n. $^{\circ}$ 5, 1940, p. 766).

\section{Caranx crysos (Mitchill)}

Depth $23 / 5$ to $31 / 5$; head $31 / 4$ to $31 / 2$. Snout $31 / 4$ to $31 / 5$ in head from tip of upper jaw; eye $31 / 2$ to $41 / 10$; maxillary $21 / 6$ to $21 / 3$; interorbital $31 / 8$ to 4 . Gill rakers 8 to $12+20$ to 25 . Seales 45 to $58+44$ or 45 in lateral line. D. I, VIII - I, 22 or 23 ; A. II - I. 19 or 20. Dark opereular spot apparently faded in small specimen, distinet in larger. Two, 88 to $240 \mathrm{~mm}$. to end of damaged caudal. No locality, likely Rio de Janeiro?

\section{Vomer setapinnis (Mitehill)}

Drawing by Richard of a specimen from Rio de Janeiro. 
Depth $12 / 5$ to $21 / 8$; head $21 / 2$ to $31 / 3$. Snout $21 / 8$ to $21 / 2$ in head from snout tip; eye $31 / 2$ to 5 ; maxillary $22 / 5$ to $27 / 8$; interorbital 5 to 6 . Gill rakers 7 to 9 (once 10 ) +24 to 33 (usually 28 ). D. VI or VII -21 to 24 ; A. I, 17 to 20 . Series of 31 specimens examined from the Atlantic coast (Rhode Island, New Jersey, Maryland, South Carolina, Costa Rica, Colon, Trinidad) Rio de Janeiro and West Africa in the Academy.

Selene vomer (Linnaeus)

One, $163 \mathrm{~mm}$. to end of demaged caudal, from Rio de Janeiro. Chloroscombrus chrysurus (Linnaeus)

Two from Rio de Janeiro. Depth $21 / 4$ to $22 / 5$. Length 138 to $143 \mathrm{~mm}$. ends of damaged eaudals.

Trachinotus falcatus (Linnaeus)

Drawing of a specimen by Richard, labeled Rio de Janeiro.

Trachinotus carolinus (Linnaeus)

Two, 20 or $21 \mathrm{~mm}$. long, from Rio de Janeiro. Compared with equally young specimens in the Academy from New Jersey, and in agreement. The smaller Brazilian specimen shows 22 or 23 soft rays and 20 to 22 soft anal rays.

\section{Stromateidae}

Peprilus paru (Linnaeus)

Depth $11 / 6$ to $11 / 2$; head 3 to $31 / 2$, width $13 / 4$ to 2 in total length. Snout $32 / 5$ to $41 / 4$ in head from upper jaw tip; eye $31 / 8$ to $41 / 5$; mouth broad, small, elosed lower jaw included; maxillary 3 to $34 / 5$ in head, not reaching eye, longer in young; teeth uniserial in jaws, small, compressed, very elose set, ends tricuspid in adult, simple in young; interorbital $21 / 5$ to $23 / 4$ in head from upper jaw tip, greatly elevated convexly. Gill rakers $5+12$ to 15 . Tubes 85 to 88 in lateral line; scales mostly minute, larger on hind median portion of trunk and cover greater portions of vertical fins, with basal striae 5 to 12 , and eireuli 40 ; young with nonstriate scales and eireuli 30 to 33 . D. III, $I V$ or $V, 39$ to 41 ; A. III or IV, III or $I V, 37$ to 39 ; front dorsal lobe $21 / 8$ to $22 / 3$ in fish without caudal; front anal lobe longer, much longer in half grown; pectoral $21 / 2$ to $33 / 4$, longest in half grown. In alcohol brownish with traces of bright silvery white reflections, more whitish below. Length 85 to $185 \mathrm{~mm}$. Two without locality, likely from Rio de Janeiro? Compared with specimens in the Academy from Colon and Massachusetts (Nantucket). Drawing by Richard of a specimen from Rio de Janeiro. 


\section{Serranidae}

\section{Acanthistius brasilianus (Cuvier)}

Depth $22 / 5$; head $22 / 5$, width 2 in its length. Snout $43 / 4$ in head from upper jaw tip, length $3 / 5$ its width; eye $41 / 8$ in head from upper jaw tip ; mouth large, lower jaw very slightly protrudes; maxillary $21 / 10$, reaches almost to hind eye edge, expansion $12 / 5$ in eye; fine teeth in narrow bands in jaws; pair of wide set canines in front above, another pair closer in front below, and canine on mandibular ramus little before middle; band of fine teeth on vomer and each palatine, none on tongue; interorbital $61 / 4$, broadly convex; hind preoperele edge finely serrate and 3 strong antrorse spines on lower edge; lower opereular spine in advance of upper, median most backward and close to lower. Gill rakers $I V, 3+12$, lanceolate. Scales $112+14$ in lateral line; tubes $52+4$ in lateral line; 25 seales abové lateral line to spinous dorsal origin, 16 above to base of seventh dorsal spine, 43 below to spinous anal origin; 70 predorsal scales; scales adherent, with 7 to 10 basal radiating striae, apical denticles 28 to 32 and circuli fine. D. XIII, 15, fifth spine $21 / 4$ total length of in head; A. III, $8, I$, second spine $21 / 2$; caudal $12 / 3$, rounded; pectoral $12 / 5$; ventral $19 / 10$. In alcohol uniform, dark dusky brown. Length $125 \mathrm{~mm}$. Rio de Janeiro.

\section{Serranus morio (Valenciennes)}

Depth $25 / 6$; head $21 / 3$. Snout $32 / 5$ in head from tip of upper jaw; eye $52 / 5$; maxillary $21 / 6$; interorbital 6 . Gill rakers $V, 4+11$, $I V$. Scales $143+14$ in lateral line; tubes $58+5$ in lateral line; 35 above lateral line to spinous dorsal origin, 19 above to soft dorsal origin, 52 below to spinous anal origin; scales with 5 or 6 basal striae, circuli moderate and terminate with 24 to 30 apical denticles. D. XI, 16, $I$, first spine $21 / 2$ in second spine, which is longest; A. III, $8, I$. In alcohol uniform dark brownish. Length $222 \mathrm{~mm}$. No locality, likely from Rio de Janeiro.

\section{Mycteroperca rubra (Bloch)}

Depth 3 ; head $21 / 2$, width 3 in its length. Snout 4 in head from upper jaw tip, long as wide; eye $42 / 3$; mouth large, mandible well protruded; maxillary $21 / 6$, reaches nearly opposite hind eye edge, expansion $13 / 4$ in eye; theeth fine, in narrow bands in jaws, several inner front upper elongated and depressible; pair of upper wide set canines, also closer set pair below; inner mandibular teeth largest and others disappear behind, though in front form rather irregular outer row; band of fine teeth on vomer and palatines, none on tongue; interorbital width $51 / 6$ in head from snout tip, slightly convex; hind preoperele edge minutely and evenly denticulate, with eluster of 4 subequal conspicuous spines at angle but none below; median opereular spine 
most backward, closer to lower, though last before uppermost. Gill rakers $21+35$, finely lanceolate. Scales $98+10$ in lateral line; tubes $74+9$ in lateral line; 21 scales above lateral line to spinous dorsal origin, 17 above to soft dorsal origin, 35 below to spinous anal origin; 80 predorsal; seales finely etenoid, with 6 to 8 basal radiating striae, 24 apical denticles and circuli fine. Supraseapula entire. D. XI, $16, I$, third spine $27 / 8$ in total head length; A. III, $11, I$, second spine $31 / 5$; candal $12 / 5$, truncate; pectoral $11 / 2$; ventral $12 / 3$. In alcohol deep brown. Brown streak from lower edge of eye towards pectoral base, another along and above upper maxillary edge down below preopercle corner. Head above and trunk marked with waved lengthwise lines and reticulated. F'ins brown, rayed vertical ones with more or less waved streaks of dark, transverse on caudal. Pectoral brown. Ventral gray black terminally. Length $165 \mathrm{~mm}$. Rio de Janeiro.

\section{Diplectrum radiale (Quoy and Gaimard)}

Depth $33 / 5$; head 3 , width half its length. Snout $41 / 5$ in head from tip of upper jaw, length $3 / 4$ its width; eye 5 ; mouth large, lower jaw slightly protruding; maxillary $21 / 4$ in head from snout tip, reaches opposite hind eye edge, expansion 3 in eye; teeth conic, in narrow bands in jaws, enlarged outer row above and still larger inner row below, also outer front lower row of enlarged teeth; inside front of upper jaw several long depressible teeth; bands of fine teeth on vomer and palatines but none on tongue; interorbital $51 / 4$ in head from snout tip, slightly convex preopercle edge serrate and 5 serrae radiate subequally at angle and extend upward full extent, though gradually smaller and then minute, but lower edge largely entire; median opercular spine much closer to lower and most backward; suprascapula with several spines. Gill rakers $I I I, 3+9, I V$, lanceolate. Scales $60+10$ in lateral line; tubes $48+4$ in lateral line; 8 scales above lateral line to spinous dorsal origin, 6 above to base of fourth spine, 15 below to spinous anal origin; 18 predorsal; seales firm, etenoid, with 9 basal radii, apical denticles 50 to 60 and circuli very fine; 10 rows of seales on cheek. D. X, $12, I$, fourth spine $21 / 3$ in total head; A. III, 7, I, third spine $42 / 3$; caudal $11 / 3$; pectoral $12 / 3$; ventral $12 / 3$. In aleohol dull brown. Length $170 \mathrm{~mm}$. Rio de Janeiro.

An example in the Academy differs from the above as follows: Depth $31 / 2$; head $22 / 3$. Scales $55+5$ in lateral line. Snout $41 / 3$ in head from upper jaw tip; eye $51 / 3$; interorbital $71 / 4$. Gill rakers $I V, 2+9, I I I$.

\section{Priacanthidae}

\section{Priacanthus arenatus Cuvier}

Depth $23 / 5$; head 3 , width $17 / 8$ in its length. Snout $23 / 5$ in head from upper jaw tip, length $3 / 5$ its width; eye $21 / 3$; maxillary 
$17 / 8$, reaches to pupil, expansion 2 in eye; teeth small, conic, in narrow bands in jaws, on vomer and front of palatines, none on tongue; interorbital $32 / 5$ in head from upper jaw tip; preoperele edge entirely denticulate, and strong flat spine at angle, its edge also denticulate. Gill rakers $7+23$, lanceolate. Seales $102+6$ in lateral line; tubes $69+4$ in lateral line; 20 seales above lateral line to spinous dorsal origin, 10 above to base of fourth dorsal spine, 34 below to anal origin; 75 predorsal scales; scales firmly adherent, with 5 basal lobes and eireuli 50 to 52 ; widely obtuse triangular subapical asperous area on each scale; 16 scales across cheek. D. X, 15 , sixth spine $21 / 4$ in total head length; A. III, 15 , second spine $22 / 3$; pectoral 2 ; ventral $11 / 6$. In alcohol uniform dull brownish. Inner ventral rays deeper brown than rest of fin. Iris dull yelowish. Length $163 \mathrm{~mm}$. to end of broken caudal. Rio de Janeiro.

An example in the Academy, also from Rio de Janeiro, differs in: Seales $114+1$ in lateral line; $79+4$ tubes in lateral line; 19 seales above lateral line to spinous dorsal origin, 35 below to spinous anal origin; seales with 3 or 4 basal lobes. Soft dorsal rays 14 ; anal rays 17 (several abnormal). Ventral membranes pale.

\section{Pomadasyidae}

\section{Haemulon steindachneri (Jordan and Gilbert)}

Depth $21 / 2$; head $22 / 3$, width $21 / 10$ in its length. Snout $12 / 3$ in head, long as wide; eye 4 ; mouth moderate, jaws even; maxillary $15 / 6$, reaches $3 / 5$ in eye, expansion $21 / 8$; bands of fine eonic teeth in at least front half of each jaw, with outer series of larger conic ones all around and continued back; front upper teeth almost twice size of lower; no others; interorbital $31 / 2$ in head, convex; hind preopercle edge with short serrae, inconspicuous, crowded about median region, more wide spread around angle, none below; preorbital width slightly greater than eye; supraseapular edge entire. Gill rakers $9+12, I I I$, lanceolate. Scales $54+10$ in lateral line; tubes $50+9$ in lateral line; 8 seales above lateral line to spinous dorsal origin, 7 above to soft dorsal origin, 14 below to spinous anal origin ; 40 predorsal ; scales finely etenoid, in oblique rows above lateral line and below anteriorly, become horizontal posteriorly, with 9 to 12 basal striae, 55 to 62 apical denticles, and circuli fine; soft vertical fins densely scaled; 16 rows across cheek. D. XII, $I, 15$, fourth spine $22 / 5$ in head, third ray 3 ; A. III, $8, I$, second spine $23 / 5$, second ray $21 / 3$; caudal $11 / 2$; pectoral $11 / 6$; ventral $13 / 5$. In alcohol dull olive brown, paler below. Fins dull brown. Each row of scales with lengthwise paler line, made up of paler or slightly yellowish spot on each scale, with series all following in courses of seales. Length $215 \mathrm{~mm}$. No locality, likely Rio de Janeiro? 


\section{Conodon nobilis (Linnaeus)}

Depth $27 / 8$; head $31 / 5$, width $19 / 10$. Snout $32 / 3$ in head from upper jaw tip, length $3 / 4$ its width; eye $33 / 4$ in head from upper jaw tip; mouth small, lower jaw slightly protruding; maxillary 3, extends little beyond front of eye, expansion $22 / 5$ in eye; narrow bands of very small conic teeth in jaws, with outer row of larger well spaced conic ones, several of each front ones as canines, but no other teeth; interorbital $34 / 5$ in head from upper jaw tip, level; preopercle edge and suprascapula denticulate, with spines at angle largest, becoming smaller above and below, with last inclined forward. Gill rakers $7+14$. Tubular seales $51+7$ in lateral line; 7 seales above lateral line to spinous dorsal origin, 5 above to soft dorsal origin, 13 below to spinous anal origin; 34 predorsal; 17 rows across cheek; seales with 7 to 12 basal striae, apical denticles 43 or 44 and circuli fine. D. XI, I, 13, I, fourth spine $13 / 5$ in total head length; A. III, $7, I$, second spine $11 / 2$; pectoral $1 \frac{1}{1 / 3}$; ventral $12 / 5$. In alcohol dull olive on back, sides and below paler with bright silvery white reflections. Faint traces of 8 vertical dark bands on back and upper sides. Fins pale brown. Length $145 \mathrm{~mm}$. to end of damaged caudal. Rio de Janeiro.

In agreement with slightly larger specimen in the Academy from Trinidad, W. I.

\section{Orthopristis ruber (Cuvier)}

Depth $21 / 2$; head $27 / 8$. Snout $23 / 4$ in head; eye $41 / 4$; maxillary $33 / 5$; interorbital 4 . Gill rakers $12+13$. Seales $53+5$ in lateral line; 10 above lateral line to spinous dorsal origin, 9 above to soft dorsal origin, 16 below to spinous anal origin; 40 predorsal; scales with 8 to 10 basal striae, apical denticles 50 to 60 and circuli moderately fine. D. XII, 15, I; A: III, 11, I. In alcohol uniform dull brownish, but slightly paler below. Length $178 \mathrm{~mm}$. Rio de Janeiro.

O. scapularis Fowler (Proc. Acad. Nat. Sci. Phila., 1915, p. 536, fig. 4. Trinidad, W. I.) is a synonym. The dark scapular blotch, so conspicuous in the type fades with long imersion in spirits. A comparison of the type in the Academy, with the above noted specimen, besides other examples also in the Academy from Rio de Janeiro and colon, 162 to $179 \mathrm{~mm}$. long. shows all in agreement. The older specimens have faded pale and are without markings.

O. kendalli Fowler (Proc. Boston Soc. Nat. Hist., vol. 35, 1917, p. 126, fig. 5. Rhode Island.) may represent the young and may thus be only an accidental northward straggler in the Gulf Stream. It shows several characters apparently not altogether of immaturity. The seales above the lateral line are in rows longitudinally parallel with the same for its entire course and in greatly reduced number as compared with those of $O$. ruber. The last has seales with 7 to 9 radiating basal striae and 27 or 28 apical denticles. 
O. poeyi Seudder, in Poey (Synopsis P. Cub. 1868, p. 312. Havana). I have not seen. Though deseribed with different coloration most of its structural characters are within the limits of variation for 0 . ruber. According to Jordan and Fesler it appears to have been founded on a more slender individual with the depth 3 1/4.

\section{Sparidae}

\section{Pagrus pagrus (Linnaeus)}

Depth $22 / 5$; head 3 , width 2 in its length. Snout $23 / 5$ in head, width $11 / 6$ in its length; eye $31 / 8$ in head, $11 / 6$ in snout; mouth little inclined from horizontal, jaws even; maxillary $23 / 4$ in head, extends slightly beyond front eye edge, expansion $23 / 4$ in eye; front of jaws with outer series of short, broad, conic teeth, those directly in front smaller and more slender; upper hind teeth molar, 5 in outer row and inner row with 3 , latter more forward; lower teeth like upper, only fewer conic ones forward; palate toothless; interorbital $31 / 5$ in head, convex; edges of preopercle, preorbital and supraseapula entire. Gill rakers $7 ?+8, I I$, lanceolate. Scales $58+10$ in lateral line; 8 above to spinous dorsal origin, 6 above to soft dorsal origin, 14 below to spinous anal origin 35 predorsal forward nearly opposite front eye edge; scales above lateral line in rows parallel, below in horizontal rows; scales erowded about body edges, on head above and along bases of rayed dorsal and anal, and out over caudal base; 7 rows across cheek; scales with 9 or 10 basal radiating striae, short apical denticles 55 to 65 , fine circuli basal. D. XII, 10, I, third spine $22 / 5$ in head; A. III, $8, I$, second spine $31 / 2$; ventral spine $21 / 3$. In aleohol dull brown, uniform. Length $125 \mathrm{~mm}$. to end of damaged eaudal. Rio de Janeiro.

\section{Archosargus unimaculatus (Bloch)}

Depth $21 / 10$; head $31 / 5$ to $32 / 5$, width $11 / 5$ to $17 / 8$ in its length. Snout $22 / 5$ to $23 / 5$ in head, width $11 / 3$ in its length; eye $31 / 2$ to $37 / 8$ in head; mouth low, small, lower jaw included; maxillary 3 to $31 / 2$ in head, reaches $3 / 4$ of space to eye ( $4 / 5$ in young), expansion $21 / 2$ to $23 / 4$ in eye; teeth as 6 notched incisors in front of each jaw, followed by triple row of molars above, with 3 of innermost each side little enlarged; lower incisors followed by double row of molars each side and 3 or 4 innermost enlarged a little; various other small or granular teeth scattered about, especially forward; interorbital 3 to $31 / 5$ in head, convex; suprascapula entire. Gill rakers $7+7$, short points. Scales 44 to $46+5$ to 8 in lateral line; 9 seales above lateral line to spinous dorsal origin, 7 or 8 above to soft dorsal origin; 30 to 38 predorsal; finely etenoid scales in even rows parallel above and along lateral line; 5 rows on cheek; scales with 12 to 20 basal radiating striae, 38 weak apical serrae and circuli very fine. D. XIII, 10 or $11,{ }^{\circ} I$, fourth spine 
$17 / 8$ in head; A. III, $10, I$, second spine $14 / 5$ to 2 ; upper eaudal lobe 1 to $11 / 10$, deeply emarginate; pectoral $1+1 / 4$ to $1+1 / 3$; ventral $11 / 4$ to $11 / 3$. In alcohol uniform brownish, with silvery white reflections. Obscure round dusky blotch, about size of eye just below lateral line opposite first dorsal spines. Length 137 to $160 \mathrm{~mm}$. Two from Rio de Janeiro. Also 2 from same locality in the Academy, included above.

A young specimen in the Wilkes collection, from Rio de Janeiro, shows: Depth $23 / 4$; head $23 / 4$, width 3 in its length. Snout $33 / 4$ in head, wide as long; eye 3 ; maxillary $31 / 6$, reaches eye, expansion 2 in eye; interorbital 4 1/2. D. XII, 11, I; A. III, 10, I. Seales 45 in lateral line. Length $38 \mathrm{~mm}$.

\section{Diplodus argenteus (Valenciennes)}

Depth $14 / 5$; head 3 , width 2 in its length. Snout $21 / 2$ in head, long as wide; eye $31 / 6$ in head; maxillary 3 , reaches to eye, expansion $21 / 2$ in eye; front of each jaw with 8 entire incisors and hind teeth as 2 rows of flat molars; interorbital 3 in head, convex; preopercle entire; least width of preorbital half of eye; suprascapula entire. Gill rakers $8+11$, lanceolate. Scales $64+2$ in lateral line; 9 scales above to spinous dorsal origin, 8 above to soft dorsal origin ; 18 below to spinous anal origin; 28 predorsal; rows of seales parallel with lateral line, but slightly smaller towards body edges, small on soft dorsal, anal and caudal bases; 5 rows across cheek; seales with 7 basal radiating striae, apical denticles 40 to 56 and circuli very fine. D. XII, 14, I, fifth spine $19 / 10$ in head; A. III, $13, I$, second spine 2 . In alcohol dull brown, sides and below scarcely paler. Length $132 \mathrm{~mm}$. Rio de Janeiro.

\section{Otolithidae}

\section{Cynoscion microlepidotus (Cuvier)}

Depth $31 / 5$; head $24 / 5$, width $22 / 5$ in its length. Snout $41 / 8$ in head from upper jaw tip, length $7 / 8$ its width; eye $47 / 8$ in head from upper jaw tip; mouth large, lower jaw well protruded; maxillary $21 / 8$, reaches opposite hind pupil edge, expansion $11 / 4$ in eye; upper teeth biserial, outer row larger and pair of front canines inside; lower teeth larger than most of upper, uniserial, mostly uniform; palate toothless; interorbital 4 in head from snout tip, broadly convex; preopercle and suprascapula with membranous edges. Gill rakers $3+6$, lanceolate. Scales $120+18$ in lateral line; tubes 58 in lateral line to eaudal base; 21 seales above lateral line to spinous dorsal origin, 19 above to soft dorsal origin; 17 below to spinous anal origin; 70 predorsal; 12 rows across cheek; several large scales close behind eye; seales cycloid, very small, largest on top of head; soft dorsal, anal and caudal largely 
covered with small seales; scales with 7 or 8 radiating basal striae and eireuli 36 to 42 . D. X - I, 21 , third spine $21 / 4$ in head; A. I, $I, 10, I$; pectoral $21 / 2$ ?; ventral $21 / 8$ ? In alcohol with back gray brown, sides and below silvery white. Iris brown. Fins pale brown. Length $171 \mathrm{~mm}$. Rio de Janeiro.

A dried skin in the Academy shows: Depth $41 / 2$; head $31 / 6$. Snout $41 / 8$ in head from upper jaw tip; eye $53 / 5$; maxillary $22 / 5$; interorbital $51 / 3$. Scales $57+7$ along lateral line; tubes $49+7$, larger on caudal base; 8 seales above lateral line to spinous dorsal origin, 8 above to soft dorsal origin, 9 below lateral line to spinous anal origin; 47 predorsal; scales with 22 radiating basal striae, blunt apical dentcles 55. D. IX, I, 20; A. II, I, 8, I; upper caudal lobe $13 / 5$; pectoral $19 / 10$; ventral $21 / 5$. In color dull brown, paler to whitish below. Narrow dark lines follow rows of seales on back and down below lateral line till level with pectoral axil, which is dusky. Fins dull brown, dorsals and eaudal with traces of pale dusky. Length $471 \mathrm{~mm}$. Buenos Ayres Argentina.

\section{Sciaenidae}

\section{Larimus breviceps Cuvier}

Depth $27 / 8$; head 3 , width $21 / 8$ in its length. Snout $47 / 8$ in head from upper jaw tip, length $3 / 5$ its width; eye $47 / 8$ in head from upper jaw tip; mouth large, nearly vertical, lower jaw protruded; maxillary 2 in head from upper jaw tip, reaches opposite front pupil edge, expansion equals eye; teeth minute, simple, conic, in narrow band in each jaw; pores on snout and chin obsolete; interorbital $33 / 4$; preopercle and suprascapula with membranous edges. Gill rakers $10+20$, lanceolate. Scales 47 along lateral line to caudal base; 6 scales above lateral line to spinous dorsal origin, 6 above to soft dorsal origin, 8 below to spinous anal origin; 25 predorsal; seales adherent, rows slightly oblique above lateral line, horizontal below; seales little smaller on predorsal, more so over most of soft dorsal, anal and caudal, radiating basal striae 10, apical denticles 36 to 43 and eireuli fine. D. IX, I, 24, I; A. II, 7, I, second spine $23 / 5$ in head; pectoral $11 / 4$; ventral $11 / 2$. In alcohol back olive brown, sides and below paler, with brassy tints. Fins dull brown, with dusky. Length $193 \mathrm{~mm}$. to end of damaged caudal. Rio de Janeiro.

Micropogon opercularis (Quoy and Gaimard)

Drawing of a specimen $164 \mathrm{~mm}$. from Rio de Janeiro.

Sciaena coroides (Cuvier)

Depth $31 / 4$; head $32 / 3$. Snout $31 / 5$ in head; eye $41 / 4$; maxillary $21 / 3$; interorbital $31 / 5$. Gill rakers $5+9$ short points. Scales 55 elose 
along and above lateral line to eaudal base, 7 seales above to soft dorsal origin, 10 below to spinous anal origin; 40 predorsal; seales finely ctenoid, with 8 basal radiating striae, apical denticles 54 to 64 and circuli very fine. D. X, I, 27, I; A. II, 6, I. Length $185 \mathrm{~mm}$. Rio de Janeiro. In agreement with 2 specimens in the Academy from St. Martins, W. I.

\section{Menticirrhus americanus (Linnaeus)}

Drawing of a specimen $165 \mathrm{~mm}$. from Rio de Janeiro.

\section{Eques acuminatus (Schneider)}

Depth $23 / 4$; head 3, width 2 in its length. Snout $31 / 4$ in head, long as wide; eye $43 / 5$ in head; mouth small, low, lower jaw inferior; maxillary $24 / 5$, upper edge concealed its whole length, reaches opposite pupil, expansion 2 in eye; teeth fine, simples, pointed, in bands in jaws, few front outer lower ones slightly enlarged and entire outer upper row enlarged, especially anteriorly; snout tip with 2 rows of pores, 3 in each row, mandible end or chin with large pore like slits, 1 median and 2 each side, of which last largest; interorbital $41 / 5$ in head, broadly convex, without supereiliary ridge; preoperele edge membranous, also supraseapula. Gill rakers $5+10$, I, lanceolate. Seales 70 elose above along lateral line to caudal base, rows 66 ; tubular scales 51 in lateral line to caudal base; 7 scales above lateral line to spinous dorsal origin, 10 below to spinous anal origin; 34 predorsal; finely etenoid seales with 8 to 10 basal marginal striae and 53 to 70 apical denticles; body scales in oblique rows erossing lateral line, largest on upper costal region; very small scales crowded over all fins; cheek with 7 rows of scales, with first to third and fifth rows enlarged. D. X - I, 37, I; third spine $15 / 6$ in head, third ray $31 / 2$; A. II, 7 , second spine $27 / 8$, seconde ray 2 ; truncate caudal $13 / 4$; pectoral $11 / 2$; ventral $11 / 2$. In alcohol dusky brown. Four obseure pale lines, $1 / 3$ of pupil in width, horizontally on sides; uppermost from suprascapula, second from upper angle of gill opening, third from upper edge of eye crosses lateral line, joins second little before depressed anal tip, then continues along upper caudal peduncle edge to eaudal base; fourth from pectoral axil. Fins deep brown. Length $178 \mathrm{~mm}$., without locality, doubtless Rio de Janeiro?

\section{Gerridae}

\section{Eucinostomus pseudogula Poey}

Depth $22 / 3$; head $31 / 5$. Snout $31 / 8$ in head, nearly long as wide; eye $31 / 5$ in head; mouth rather small, closed lower jaw little shorter; maxillary $27 / 8$, reaches slightly beyond front edge of eye, expansion 3 in eye; teeth finely villiform, in bands in jaws; interorbital $24 / 5$ in head, broadly convex; preopercle and preorbital edges entire. Gill 
rakers $V I, 4+7$, short rudimentary points. Tubular scales $46+2$ in lateral line; 6 scales above lateral line to spinous dorsal origin, 4 above to soft dorsal origin, 10 below to spinous anal origin; 22 predorsal; rows above lateral line parallel with its course, below in horizontal rows; dorsal and anal with broad basal scaly sheaths; axillary ventral flap half length of fin; caudal scaly basally, fine scales over most of lobes, also over lower surfaces of ventrals as depressed; cheek with 3 rows of scales to preopercle ridge and several scales on flange above angle; muzzle naked, squamous area reaches to hind nostril and median naked area nearly closed in front by approximating scales; scales with 5 basal radiating striae and circuli very fine. D. IX, 10, I, second spine $14 / 5$ in head; A. III, 7, I, second spine 4, third 3 ; upper caudal lobe $11 / 3$ ?; pectoral apparently little longer than head; ventral $12 / 3$. In alcohol brownish, apparently faded, back somewhat olive. Sides below level of upper eye edge pale, with silvery tints. Iris and fins brownish, upper edge of spinous dorsal dusky. Length $130 \mathrm{~mm}$. to end of demaged caudal. Rio de Janeiro.

\section{Diapterus brasilianus (Cuvier)}

Depth $21 / 4$; head $31 / 4$, width 2 in its length. Snout $31 / 3$ in head from upper jaw tip, length $7 / 8$ its width; eye $31 / 2$ in head from snout tip; mouth moderate, lower jaw very slightly protruding; maxillary $23 / 4$ in head from snout tip, reaches opposite front pupil edge, expansion $24 / 5$ in eye; teeth fine, conic, in narrow bands in jaws; interorbital $31 / 4$ in head from snout tip, broadly convex; preopercle and preorbital edges finely serrated. Gill rakers $20+11$, lanceolate, short. Scales $36+2$ in lateral line; 6 above lateral line to spinous dorsal origin, 5 above to soft dorsal origin, 11 below to spinous anal origin; 17 enlarged predorsal seales to occiput and 37 more small ones anteriorly until opposite front eye edges; scales cycloid, rows above lateral line parallel, below horizontal; dorsals and anals with broad basal scaly sheaths, former of very large uppermost marginal row of seales and basally many small scales; anal with 2 rows basally of subequal scales and many small ones about bases; ventral with axillary scaly flap; caudal scaly, basally scales little smaller than on caudal peduncle while other scales very small; 4 rows of large scales on cheek to preopercle edge and 8 or 9 rows of very small scales on suborbital; preopercle limb with small scales; muzzle naked, squamous area beginning with small scales convexly opposite hind nostrils; ventral covered with small scales; scales with 5 basal radiating striae and circuli very fine. D. IX, 10, I, second spine $13 / 4$ in total head length, first ray $22 / 3$; A. III, $7, I$, second spine $12 / 5$, first ray $19 / 10$; forked caudal with lower lobe $11 / 6$; pectoral $11 / 6$ ?; ventral $12 / 5$. In alcohol faded dull brassy brown, searcely paler below. Each row of scales on trunk with broad deeper brown median lengthwise band, 6 above lateral line and 10 below, though 
lower of latter region pale. Fins brown. Iris brown. Length $205 \mathrm{~mm}$. No locality, likely Rio de Janeiro?

\section{Latilidae}

\section{Pseudopercis numida Ribeiro}

Depth $42 / 5$; head $31 / 4$, width $19 / 10$ in total head length. Snout $31 / 5$ in head from upper jaw tip, long as wide; eye 5 in head from upper jaw tip, reaches to eye; bands of simple, conic teeth in jaw, outer row little enlarged and each tooth slightly curved; no teeth on palate; interorbital 5 in head from snout tip, slightly convex; preopercle edge denticulate and denticles covered with skin. Gill rakers $I I, 3+6, I I$, short fleshy points. Scales 75 in lateral line to caudal base; tubes $70+12$ in lateral line; 9 seales above lateral line to soft dorsal origin, 23 below to anal origin; seales with 15 to 22 basal radiating striae, 30 to 42 apical denticles and basal circuli fine, marginal coarser; small scales on top of head around suborbital region, opereles and cheeks, other seales on head moderate; edge of snout, lips, maxillary and mandible naked or skin coriaceous. D. V, 27 ; A. 23. In alcohol uniform umber, little paler or ochraceous below. Fins dull brownish, dorsals little darker marginally and ventrals with innermost ray pale like ventrals. Length $300 \mathrm{~mm}$. No locality, doubtless from Rio de Janeiro?

The above specimen differs from Ribeiro's account (Archiv. Mus. Nac. Rio de Janeiro, vol. 17, 1915, p. 9, pl., upper figure) in having the "vomer provido de dentes curtos, obtusos, os palatinos duma fila d'outros menores'. In my specimen the vomer is covered with thick, small close-set papillae and a few scattered papillae are found over the palatine region and elsewhere on the roof of the mouth. Ribeiro gives 7 dorsal spines, anal rays 27 , and 88 seales in the lateral line.

\section{Pinguipes brasilianus Cuvier}

Depth $41 / 6$; head $33 / 4$, width $13 / 5$ in its length. Snout $22 / 5$ in head, width $11 / 6$ in its length; eye 5 ; broad lips tough, finely papillate; jaws with outer row of more or less uniform conic teeth, inside band of small simple teeth, wide in front of jaws and narrowing behind; 6 low broad conic teeth on vomer; maxillary $22 / 3$ in head; interorbital 5 , nearly level; preopercle edge entire. Gill rakers $7+8$, lanceolate. Scales 100 along lateral line to caudal base; 75 scales in lateral line to caudal base; 17 scales above lateral line to soft dorsal origin, 26 below to anal origin; 50 predorsal; snout, preorbital and front half of interorbital naked; 14 rows of seales across cheek to preopercle angle; 10 to 12 basal radiating striae on scales, apical denticles 26 to 32 , lateral circuli coarse and basal fine. D. VII, 26 ; A. 25 . In alcohol dull brown, belly seareely paler. Soft dorsal with lengthwise submarginal dusky band. Length $234 \mathrm{~mm}$. Rio de Janeiro. 


\section{Chaetodontidae}

Chaetodon striatus Linnaeus

Depth $11 / 2$; head 3 , width $17 / 8$ in its length. Snout 3 in head; eye 3 ; maxillary $34 / 5$; interorbital $23 / 4$. Gill rakers $5+10$, short weak points. Tubes 39 in lateral line; 43 scales between supraseapula and eaudal base; 7 scales above lateral line to spinous dorsal origin, 18 below to spinous anal origin; 56 predorsal; scales with 11 basal radiating striae and 82 apical denticles. D. XII, 21, I; A. III, $17, I$. In alcohol pale to whitish brown, each row of scales on trunk with dark median streak. Dark brown band from predorsal down to eye and below across cheek, edged paler. Another wider dark brown band from front portion of spinous dorsal till behind ventral bases. Third broad dark brown band from last part of spinous dorsal down to front of anal. Fourth brown band over eaudal peduncle. Dorsals and anals edged narrowly whitish, broader on eaudal and latter with submarginal dark brown band. Pectoral brown. Ventral blackish, front edges pale brown. Length $105 \mathrm{~mm}$. Rio de Janeiro.

\section{Geophagus brasiliensis (Quoy and Gaimard)}

Depth $22 / 5$; head $23 / 4$, head width $19 / 10$ in its total length. Snout $21 / 5$ in head from upper jaw tip; eye $37 / 8$; maxillary $31 / 8$; Interorbital $32 / 5$. Gill rakers $5+10$, short, mostly tubercular. Upper arch of lateral line 20, horizontal section with $10+2 ; 5$ seales between spinous dorsal origin and lateral line, and 2 above to soft dorsal origin; 9 below upper arch of lateral line to spinous anal origin; 14 predorsal scales; scales with 10 to 13 basal radiating striae and apical denticles 100 to $115 ; 6$ rows of seales on cheek. D. XV, 11; A. III, 8; caudal convex behind. In aleohol mostly uniform dull brownish. Length $122 \mathrm{~mm}$. Rio de Janeiro.

\section{Pomacentridae}

Pomacentrus fuscus Cuvier

Drawing of a specimen $125 \mathrm{~mm}$. long, by Richard, from Rio de Janeiro. Abudefduf saxatilis (Linnaeus)

Drawing of a specimen $145 \mathrm{~mm}$. long, by Richard, from Rio de Janeiro.

\section{Labridae}

Halichoeres poeyi (Steindachner)

Depth $32 / 5$; head $31 / 4$, width $22 / 5$ in its length. Snout $21 / 2$ in head, width $11 / 4$ in its length; eye $62 / 3$ in head; maxillary $34 / 5$; 
interorbital $51 / 2$, Gill rakers $6+12$, short points. Seales $27+3$ in lateral line; 3 above to spinous dorsal origin, 2 above to soft dorsal origin, 8 below to spinous anal origin; 7 predorsal seales; scales with 50 to 54 basal radiating striae and 32 to 42 apical, median connecting reticulations rather imperfect; tubes in lateral line simple to 5-branched. D. IX, 10, I; A. II, 11, I. In alcohol faded dark dusky olive, little paler or more olive below. Traces of 3 slightly paler brownish horizontal bars on operele, uppermost level with lower edge of eye and median opposite rictus. Length $184 \mathrm{~mm}$. Rio de Janeiro.

Comparison with slightly smaller specimens in the Academy from St. Lucia and Trinidad, W. I., are without trace of the dark bloteh behind the eye or the dark basal pectoral bar.

\section{Percophidae}

Percophis brasiliensis Quoy and Gaimard

Depth $27 / 7$; head $35 / 6$, width $21 / 5$ in its length. Snout $22 / 3$ in head from upper jaw tip, depressed, long as wide; eye $611 / 2$; mouth moderate, lower jaw produced; maxillary $23 / 5$, reaches $2 / 5$ in eye, expansion 2 in eye; teeth in jaws uniserial, moderate, 6 upper canines in front and 8 well developed lateral ones; bands of fine teeth across vomer and palatines and outer row on latter slightly enlarged; interorbital $11 / 3$ in eye, level. Gill rakers $7+17$, slender, lanceolate. Scales 108 in lateral line to eaudal base; 10 seales above lateral line to spinous dorsal origin, 21 below to spinous anal origin; 68 predorsal; 18 rows across cheek to preopercle ridge; scales with 10 basal radiating striae, apical denticles 25 and basal circuli fine, upper and lower marginal coarse. D. VIII - 30; A. 37. In aleohol uniform dull brownish. Length $280 \mathrm{~mm}$. to end of damaged caudal. Rio de Janeiro.

\section{Gobiidae}

\section{Garmannia hemigymna (Eigenmann and Eigenmann)}

Depth 4 to 5 ; head 3 to $31 / 6$, width $12 / 3$ to $14 / 5$ in its length. Snout $33 / 4$ to $42 / 3$ in head, length. $2 / 3$ to $3 / 4$ its width; eye $31 / 3$ to $37 / 8$; maxillary $21 / 4$ to $22 / 5$, reaches little behind pupil, but not quite to hind eye edge; lower jaw slightly shorter than upper; conic teeth large, rather strong, uniserial above, biserial below, with inner row little larger than fewer; tongue truncate; interorbital $21 / 4$ to $21 / 3$ in eye, narrow, nearly level. Gill rakers $2+8$, lanceolate. Scales 38 or $39+2$ from near pectoral axil to eaudal base; 5 ou 6 transversely from soft dorsal origin, 10 across eaudal peduncle transversely; seales mostly on posterior part of body, extend forward over costal region to pectoral axil and not along upper and lower body edges at front of soft dorsal 
and anal; rádiating basal striae 9 to 16 , apical denticles 10 to 12 and eirculi coarse. D. VII -12 or 13 ; A. 10. In alcohol uniform dull brownish. with faint dark mottlings on back and on fins terminally, which latter are otherwise pale. Length 28 to $30 \mathrm{~mm}$. Two from Rio de Janeiro.

Previously only known from the original deseription without locality and supposed to be somewhere in the West Indies. The type is $44 \mathrm{~mm}$. long and has fewer fin rays than the above specimens.

\section{Clinidae}

Labrisomus nuchipinnis (Quoy and Gaimard)

Depth $31 / 5$; head $31 / 3$, width $12 / 3$ in its length. Snout $31 / 3$ in head; eye $51 / 3$; maxillary 2 ; interorbital 8 . Gill rakers $3+6$, lanceolate. Scales 70 along and close to lateral line to caudal base; tubular seales $64 ; 10$ above lateral line to soft dorsal origin; 15 below to anal origin; seales with 18 to 21 basal radiating striae and eirculi rather coarse. D. XVIII, 13; A. II, 21. In alcohol umber brown. Dark brown vertieal bloteh, narrower than eye, but equals eye in vertical diameter. Length $147 \mathrm{~mm}$. Rio de Janeiro.

\section{Blenniidae}

Hypleurochilus geminatus (Wood)

Depth $33 / 5$; head $32 / 5$, width $12 / 5$ in its length. Snout 3 in head, convex, rather inclined, length $3 / 4$ its width at front of eye; eye $31 / 6$ in head, high; supraorbital tentacle with fringe of 5 slender points; maxillary 3 in head, reaches to pupil; mouth terminally inferior, lower jaw little shorter; teeth 24 above, 20 below, uniserial, compressed, slender and canine each side behind, lower of which little longer; interorbital 2 in eye, concave. Gill opening wide as pectoral base. D. XII, 15; A. 18. In alcohol uniform dull brownish, any markings if present in life now faded out. Length $45 \mathrm{~mm}$. No locality, likely from Rio de Janeiro.

Compared with the type of Blennius geminatus Wood in the Academy, from Charleston, S. C.. It has the same number of teeth and much larger and stronger canines (Acad. Nat. Sci. Phila. Monogr. n. ${ }^{\circ}$ 7, 1945, p. 153, fig. 302$)$.

\section{Parablennius pilicornis (Cuvier)}

Depth $33 / 4$; head $31 / 2$, width $13 / 5$ in its length. Snout 3 in head, convex, length $4 / 5$ its width; eye $43 / 4$ in head; maxillary $21 / 5$, reaches to hind eye edge, expansion $11 / 4$ in eye; teeth in jaws uniserial, even, compressed or incisor like, 24 above, 28 below; canine above and below 
each side posteriorly; interorbital width 2 in eye, convex. Fringed tentacle above each eye half its diameter in length. Gill rakers 10 ? short rudimentary points. Lateral line to soft dorsal, pores 23 . D. XII, 21; A. I, 23. In aleohol uniform blackish. Length $135 \mathrm{~mm}$. Rio de Janeiro.

Valenciennes gives the supraorbital tentacle more than a fourth of the head length, upper teeth 26, lower 24 and head $41 / 2$ in body with caudal, in my specimen 4. His examples were 128 to $152 \mathrm{~mm}$. long (Hist. Nat. Poiss., vol. 11, 1836, pp. (187) 254. Rio de Janeiro).

\section{Emblemariidae}

\section{Emblemaria atlantica Jordan and Evermann}

Depth 4 to $43 / 4$; head 3 to $37 / 8$, width 2 . Snout $31 / 3$ to $42 / 5$ in head, length $2 / 3$ width; eye $31 / 6$ to $31 / 2$, little elevated, without tentacle; maxillary $17 / 8$ to 2 in head, reaches well beyond eye; teeth strong, conic, simple, uniserial in jaw, on vomer and palatines; interorbital $12 / 3$ to 2 in eye; teeth strong, conic, simple, uniserial in jaws, on vomer and palatines; interorbital width $12 / 3$ to 2 in eye, narrow, concave. Gill rakers 7 ? short, rudimentary feeble points. No lateral line. D. 28 to 30 , elevated in front, first spine ends in filament and long as head; A. 22 or 23 . In alcohol dull russet, with 8 obseure deeper cross bars. Spinous dorsal blackish in front, filament whitish. Anal edge dusky and dark blotch on each ventral. Dark transverse bar at caudal base. Two, 34 or $35 \mathrm{~mm}$. Rio de Janeiro.

The original account (Bull. U. S. Nat. Mus., n. ${ }^{\circ} 47$, pt. 3, 1898, p. 2.402. Pensacola, Florida) is based on a specimen $90 \mathrm{~mm}$. long, apparently differing only as a change with age. E. pandionis Evermann and Marsh is apparently a young specimen of $38 \mathrm{~mm}$. The comparisons given by these authors (Bull. U. S. Fish Comm., vol. 20, pt. 1, 1900 (1902), p. 318, fig. 104. Off Porto Rico, W. I.) are not satisfactory. The figure shows longer ventrals than either of my specimens.

\section{Scorpaenidae}

Scorpaena brasiliensis Cuvier

Depth 3 ; head $21 / 2$, width $17 / 8$ in its length. Snout $37 / 8$ in head from upper jaw tip, long as wide; eye $41 / 4$; maxillary $21 / 8$, reaches to hind eye edge; interorbital $54 / 5$, deeply concave. Head well armed and ridges prominent. No supraorbital tentacle. Gill rakers $7+10$, low compressed tubercles. Tubes $23+2$ in lateral line; $44+4$ scales in lateral line; 8 scales above lateral line to dorsal origin, 19 below to spinous anal origin; scales with 15 to 17 basal radiating striae and circuli fine; head scaly, also prepectoral region. D. XI, I, 10; 
A. III, $5, I$, second spine little shorter than third. In aleohol dull brown, variegated with paler and darker, some on head and fins. Length $185 \mathrm{~mm}$. Rio de Janeiro.

\section{Triglidae}

\section{Prionotus punctatus (Bloch)}

Depth $41 / 3$; head $22 / 3$, width $13 / 5$ in its total length. Snout $21 / 10$ in head from upper jaw tip; eye $63 / 5$; maxillary $21 / 3$; borry interorbital $74 / 5$, concave. Gill rakers $3+13$, lanceolate. Seales 95 in lateral line to caudal base; tubes $50+2$ in lateral line; 8 seales above lateral line to soft dorsal origin, 24 below to anal origin; 15 predorsal; scales with 4 to 6 basal radiating striae, 24 to 28 apical denticles and circuli fine. D. X -12 ; A. $11, I$; pectoral reaches $11 / 3$ to eaudal base. In alcohol dull brownish above, lower or under surfaces paler to whitish. Head above entirely elosely spotted with dull brown, and small spots much smaller than pupil. Fins, except ventral and anal, with brownish spots on rays or spines. Pectoral dusky brown, 5 dark blotches large as eye above, also upper rays of fin pale with intervening brown eross bars. Length $192 \mathrm{~mm}$. No locality, probably from Rio de Janeiro.

\section{Cephalacanthidae}

\section{Cephalacanthus volitans (Linnaeus)}

Depth $53 / 4$; head $33 / 5$. Snout 3 to $31 / 6$ in head; eye $21 / 2$; maxillary 3 ; interorbital 2 . Scales $60+3$ in axial lateral series; 22 to 24 transversely between soft dorsal and anal origins; 7 predorsal. D. II, $\mathrm{V}-8$; A. 6 ; depressed pectoral reaches within $2 / 5$ an eye diameter of caudal base. In alcohol brown, body paler below. Head above speckled or mottled obscurely with darker. Spinous dorsal dusky brown. Soft dorsal with dull brown spots. Pectoral whitish medially on lower or outer surface, otherwise deep blackish brown and some obseure blackish blotche on upper surface. Length $140 \mathrm{~mm}$. Rio de Janeiro.

\section{Batrachoididae}

\section{Nautopaedium porosissimum (Valenciennes)}

Depth 6 to $61 / 4$, width 2 to $21 / 3$ in its total length. Snout $41 / 6$ to $41 / 3$ in head from upper jaw tip; eye 7 to 8 ; maxillary $17 / 8$ to 2 , extends slightly beyond eye, expansion equals eye; mouth wide, lower jaw well protruded; single row of small teeth in jaws, on vomer and palatines, several enlarged along palatines and lower jaw; upper outer teeth very small; interorbital $31 / 2$ to 4 in head from upper jaw tip, 
level; opercle ends in strong straight spine directed backward. Gill rakers $1+15$, lanceolate. Shining pores conspicuous, upper lateral row wide set, lower lateral row close set, series extending from side of costal region till above hind anal rays or $3 / 4$ of anal base; close along anal base row of wider spaced pores each side its entire extent; row of close set pores along edge of lower lip; row over lower face of mandible, also row extends along each side of throat to branchiostegal row from breast each side, within ventrals, behind which joined by another branch above and still another from pectoral base, then extend back along each side of abdomen below; inside area of last long loup formed from snout nearly to ventral bases; several short rows of pores on operele and side of head. D. II -35 or 36 ; A. to 35 . In alcohol dull brown, whitish below on head and belly. Four, 73 to $85 \mathrm{~mm}$. Rio de Janeiro.

\section{Monacanthidae}

\section{Monacanthus ciliatus (Mitchill)}

Depth $11 / 2$; head $31 / 5$. Snout $11 / 5$ in head; eye $23 / 5$; interorbital $23 / 4$. Gill opening $11 / 2$ in eye. Skin velvety, without spines on caudal peduncle. D. II -32 ; A. 22 ; pectoral 15 . Dorsal spine inserted behind hind eye edge, row of moderately strong spines along each hind edge, eurved downward. Moderate skinny flap behind ventral flap, but not extending beyond; spine small and with few spinules. In alcohol dull brown, with obscure darker markings. Fins dull brown. Length $58 \mathrm{~mm}$. No locality, probably from Rio de Janeiro.

\section{Monacanthus hispidus (Linnaeus)}

Depth $11 / 2$ to $13 / 4$; head $31 / 10$ to $31 / 5$, width $17 / 8$ to 2 . Snout $11 / 3$ in head; eye $23 / 5$ to $31 / 8$; interorbital $24 / 5$ to 3 . Gill opening $1 \frac{1 / 2}{2}$ to $13 / 5$ in eye. No ventral flap. Skin velvety, without spines on caudal peduncle. D. II - 32 or 33, spine inserted over or close behind hind eye edge, finely asperous and with row of decurved strong spines along each hind edge; A. 32 ; pectoral 13 or 14 . In alcohol dull brownish, mostly uniform, or with few darker or nebulous areas. Often several ill defined dark blotehes along bases of soft dorsal and anal. Two, 59 to $86 \mathrm{~mm}$. Rio de Janeiro.

\section{Tetrodontidae}

Sphoeroides spengleri (Bloch)

Depth 4 ; head $24 / 5$. Snout 2 in head; eye $41 / 8$ to $47 / 8$; bony interorbital $61 / 5$ to $71 / 2$, concave; head width $12 / 5$ to $11 / 2$. Predorsal, oceiput and belly prickly, sides, rest of head and trunk smooth. D. $I I, 6$; 
A. II, 5. In alcohol dull brown, marbled paler and darker above, lower surface whitish. Row of 12 blackish blotches along side below, from chin to pectoral base and thence to lower surface of caudal peduncle. Two, 90 to $125 \mathrm{~mm}$., Rio de Janeiro.

\section{Sphoeroides marmoratus (Ranzani)}

Depth $31 / 5$ to $31 / 4$; herd $21 / 2$ to $27 / 8$. Snout $17 / 8$ to $21 / 3$ in head; eye 4 ; bony interorbital 8 , concave; head width $12 / 3$. Body finely prickly, except muzzle, trunk opposite dorsal and anal and caudal penduncle; prickles above extend from dorsal to front eye edge, below from chin to vent and along lower sides of head, few small inconspicuous prickles behind pectoral, not in axil. D. II, 6; A. I, 5 or 4 ?. In alcohol dull brownish to dark slaty, paler specimen little lighter below. Two, 34 to $95 \mathrm{~mm}$., one evidently by error "Oahu", the other without locality, likely both from Rio de Janeiro?

\section{Diodontidae}

\section{Chilomycterus spinosus (Linnaeus)}

Depth $22 / 5$; head $27 / 8$; body width $22 / 5$ in standard length. Snout $23 / 5$ in head; eye 4 ; mouth width $21 / 2$; interorbital $11 / 2$; gill opening $43 / 4$. Simple undivided nasal tentacle. Interorbital broadly concave. Spines all 3-rooted, pair of supraoculars and supereiliary edge not especially elevated; median spine at front of interorbital D. I, 9?; A. $I, 10$; pectoral $I, 21$. In alcohol uniform dark brownish, at present without any trace of markings. One, $185 \mathrm{~mm}$. to end of damaged eaudal, without locality, likely from Rio de Janeiro?

The above in poor preservation, without any color pattern. Comparison with C. geometricus (Walbaum) from New Jersey, and C. antennatus (Cuvier) from Colon, reveal no structural differences.

\section{PATAGONIA $1839^{\circ}$}

Rio Negro, January 26 to February 1. On approaching the mouth of the Rio Negro the coast did not appear so low as was anticipated. It is not as low as the coast of our Middle and Southern States; but the eye being unaceustomed to a shore destitute of timber, may very readily be decieved as to its actual elevation. From about 3 miles south of the river to an undetermined distance northward, the coast is composed of low sand hills, from 20 to 30 feet in elevation, and for the most part fixed by a seattered growth of grasses and other plants. Back of these, and eastward of the river, is an irregular range of "Downs" or hills of drifting sand of considerable extent and extending an undetermined distance eastward. 
The width of the river (perhaps a third of a mile) and the quantity of water it earried surprised me, considering that its chief supplies must probably be drawn from near its sources. Though not widening materially at its mouth, it is deep, and the current rapid and mostly downwards, a tide of 10 feet (it was said) only reversing it for about 2 hours. The water is fresh to its very mouth, except at the top of the tide-along the immediate margin, however, or other side, the water is brackish though still potable, but the shores for a mile or 2 from the mouth seem impregnated with salt.

About 2 miles up the shore is here very shelving and gravelly, and rather composed in good part of small, polished as if "sea-worn" pebbles in great part reddish and porphyritic, strongly resembling in their diminutive size, those at Nahant; quartz on pebbles were in the same manner mixed with them, some semitransparent. (P.)

\section{Scyliorhinidae}

Scyliorhinus bivius (A. Smith)

This is a species of dog fish, taken by the line, spotted and not exceeding 18 inches. While living it made an occasional puffing, produced by taking air into the oesophagus. (P.)

\section{Pimelodidae}

\section{Pimelodus albicans (Valenciennes)}

On first putting down our lines at the anchorage we obtained some cat fish. The quantity of fresh water poured out by the river diminished - the marvel in some respects; but the stomach of one examined was full of Palaemonidae and other small marine crustacea. We afterwards observed it taken by "lay out" lines at the mouth of the river, and it appears to be the most abundant fish here. Grows to the weight of $3 \mathrm{lbs}$. General color whitish, changing into slate on the back, tail forked and

- fins generally elongated, approaching Bagrus in this respect. (P.)

\section{Otolithidae}

\section{Cynoscion striatus (Cuvier)}

Depth $33 / 5$; head $27 / 8$. Snout $41 / 8$ in head from upper jaw tip, long as wide; eye 5; maxillary $21 / 4$, reaches opposite hind pupil edge; mouth large, lower, jaw well protruded in front; upper teeth biserial, outer row larger, 3 forward canines, of which 2 slender, long and simple; lower teeth uniserial laterally, little smaller and as narrow band 
in front; no teeth on palate; interorbital $43 / 5$ in head from upper jaw tip, broadly convex; preopercle and supraseapular edges membranous, fringed. Gill rakers $9+16$, lanceolate. Scales $59+8$ in lateral line; tubes 48 in lateral line to eaudal base; 8 above lateral line to spinous dorsal origin, 8 above to soft dorsal origin, 9 below to anal origin; 53 predorsal; scales in inclined rows slightly forward before anal, then horizontal; soft dorsal, anal and caudal largely with small seales, also breast and chest; scales with basal radiating striae 11 to 13 , apical denticles 34 to 42 and circuli 90 to $135 ; 12$ rows across cheek to preopercle ridge. D. X, I, 19 ; A. II, $9, I$; pectoral $21 / 5$ in head; ventral $19 / 10$ ? In alcohol dull brownish with brassy tints, paler below. Each row of scales with pale median streak, darker edges bordering each side so intervening darker ones about equally wide. Fins brown, also iris. Length $187 \mathrm{~mm}$.

A small specimen, figured by Mr. Drayton, taken by line. (P.)

\section{Sciaenidae}

\section{Ophioscion adustus (Agassisz)?}

Listed as Corvina. A fine species, was taken with the line, at the anchorage, much resembling the Micropogon, but without beards; and in like manner having oblique lines. The first spine of the anal fin not particularly strong. Weight about $3 \mathrm{lbs}$. We understood this was the fish usually called cod on the coast. (P.)

Paralarimus patagonicus Fowler and Bean

Paralarimus patagonicus Fowler and Bean, Proc. U. S. Nat. Mus., vol. 63, 1923, p. 18. Northern Patagonia. - Fowler, Proc. Am. Philos. Soc., vol. 82, n. $^{\circ} 5,1940$, p. 776 , fig. 56 (type).

Odontoscion dentex (Cuvier)

Drawing of a specimen $162 \mathrm{~mm}$. from Patagonia.

Micropogon opercularis (Quoy and Gaimard)

Depth $33 / 5$; head 3 , width $21 / 4$ in its length. Snout $33 / 5$ in head, length $5 / 6$ its width; eye $41 / 2$; mouth small, low, lower jaw well included; narrow lips finely papillose; maxillary $21 / 2$ in head, reaches opposite pupil, expansion $23 / 4$ in eye; bands of small conic teeth in jaws, outer row little enlarged; lower teeth smaller; each side of snout in front short marginal slit at front preorbital edge; chin with 4 pores; inner borders of mandibular rami in front each with 4 short even barbles; interorbital 4 in head, broadly convex; hind preopercle edge denticulate, denticles larger below to corner, where 2 largest, widely separate, upper 
longer and broad lower directed down and backward; supraseapula membranous, sealy. Gill rakers $7+12, I I I$, lanceolate. Scales 57 in lateral line to caudal base; tubes 50 in lateral line to caudaI base; 7 scales above lateral line to spinous dorsal origin and 8 below to spinous anal origin; 42 predorsal; scales weakly ctenoid, in backward inclined lengthwise rows, smaller on chest, each side of breast, prepectoral, predorsal, narrowly on soft dorsal and anal basally, over most of eaudal and bases of paired fins; basal radiating striae 11 or 12 , apical denticles 33 to 39 and circuli fine; cheek with 12 rows of scales, first 4 or 5 rows enlarged. D. X, I, $30, I$, third spine $21 / 4$ in head, second ray 3 ; A. II, 9, I, second spine $23 / 4$, second ray $21 / 3$; pectoral $12 / 5$; ventral $14 / 5$. In alcohol dusky gray on back, sides and below paler, all with deep silvered sheen. Traces of dark lines follow obliquely in seale rows, each line medially along row. Fins and iris brown. Length $145 \mathrm{~mm}$. to end of damaged caudal. No locality, likely from Patagonia.

A dry skin in the Academy, from Buenos Aires shows: Depth 4; head $31 / 2$. Snout $31 / 4$ in head; eye 7 ; maxillary $27 / 8$; teeth subequal in size, outer upper very little larger; interorbital $31 / 2$ in head; 2 large preopercle denticles at corner directed down, others above but slightly developed. Scales $58+6$ in lateral line; tubes $50+7$ in lateral line; 7 seales above lateral line to spinous dorsal origin, 7 above to soft dorsal origin and 9 below to spinous anal origin; 33 ? predorsal; seales with 12 basal striae largely median and not reaching edge, and apical denticles 38. D. X, I, I, 26, I, third spine $21 / 4$ in head; A. II, $8, I$, second spine $51 / 6$, second branched ray $21 / 3$; pectoral $12 / 5$; ventral $17 / 8$. Pale brown, very light below. Back with narrow, well defined deep brown lines, 1 to each row of seales, usually little less than $1 / 3$ its exposure width, slightly waved and some of lower ones little broken or irregular. Slight dusky shade in axilla. Fins brown, with dusky shade at end of spinous dorsal. Length $516 \mathrm{~mm}$.

\section{RESUMO}

Na viagem efetuada à volta do mundo pela U. S. Exploring Expedition mais conhecida pelo nome de Expedição Wilkes e durante o período em que a mesma operava no Atlântico Ocidental, foram visitadas as regiões do Rio de Janeiro e da Patagonia.

Por ocasião da festa comemorativa do centenário da The American Philosophical Society, de Filadelfia, ocorrida a 23 de Fevereiro de 1930, o autor teve a oportunidade de apresentar uma nota prévia da qual constava uma lista de peixes capturados durante o eruzeiro da Expediẹão. Teve, então, o ensejo de examinar o diário redigido pelo Dr. Charles Pickering, botânico da Expedição, nêle encontrando anotações valiosas para a História Natural, considerada em seu sentido amplo, detalhes a respeito das localidades pereorridas e relações extensas de animais e 
plantas, além de diversos representantes pertencentes a outros grupos. Sob o ponto de vista histórico, os comentários aí constantes são de importância significativa. Em muitos casos, essas apreciações fornecem base sólida para a efetivação de estudos faunísticos, de caráter comparativo, muito instrutivos e úteis.

O autor examinou a coleção de peixes da Expedição Wilkes que se encontra no Museu Nacional dos Estados Unidos, em Washington, acêrvo êsse gentilmente posto à sua disposição para estudo. Dessa maneira, no presente trabalho, fornece matéria de amplo interêsse histórico, visando com isso lançar alguma luz sôbre a imensa fauna do Brasil e da Argentina.

Baseando-se nos dados fornecidos por Pickering, o autor divulga dados curiosos a respeito da baía do Rio de Janeiro e adjacências, no ano de 1838. Segue-se uma lista contendo a diagnose de 82 espécimes de água doce, salobra e salgada, estudados e comparados com outros de várias procedências.

Referindo-se ao Rio Negro, desereve o autor o aspeto da região patagônica, durante certo período de 1839 , fazendo comentários a respeito de 7 espécies de peixes nela.encontradas. 